\title{
KEPUASAN KONSUMEN DAN KINERJA KEUANGAN UKM DI KABUPATEN JEPARA
}

\section{CONSUMER SATISFACTION AND FINANCIAL PERFORMANCE OF SMES IN JEPARA INDONESIA}

\author{
Hadi Ismanto ${ }^{* 1}$ \\ *) Fakultas Ekonomi dan Bisnis, Universitas Islam Nahdlatul Ulama Jepara \\ Jl. Taman Siswa no. 9 (Pekeng) Tahunan Jepara
}

\begin{abstract}
Jepara regency is one of the districts in Indonesia which has a very small and medium business that is a number of 56,534,592 SMEs and as many as 16 sectors of SMEs scattered in Jepara regency. But many SMEs have not been able to maintain the quality of products and services to customers and financial management is not good. Increased competition has caused many SMEs only looking for short-term profitability so that many SMEs have failed. The purpose of this study is to examine the influence of customer relations and product quality on customer satisfaction, and the influence of customer satisfaction on financial performance. This study was conducted on SMEs with the criteria of having a workforce of 5-99 people, net worth other than land and buildings of $\leq 500$ million, and the accumulated sales for one year amounted to $\leq 2.5$ billion. The sample used as many as 183 owners of SMEs in Jepara district spread across 16 types of business. The results showed that customer relationship and product quality have a positive and significant influence on customer satisfaction, while consumer satisfaction has a positive and significant impact on financial performance. SME owners believe that having a good customer relationship causes consumers to be satisfied with SMEs and will maintain loyalty to buy back the resulting product to improve the financial performance of SMEs.
\end{abstract}

Keywords: SMEs, costumer satisfaction, finacial performance, product quality, customer relationship

\begin{abstract}
Abstrak: Kabupaten Jepara merupakan salah satu kabupaten di Indonesia yang memiliki usaha kecil dan menengah yang sangat banyak yaitu sejumlah 56.534.592 UKM dan sebanyak 16 sektor UKM yang tersebar di Kabupaten Jepara. Namun, banyak UKM belum mampu menjaga kualitas produk dan layanan kepada pelangan serta pengelolaan keuangan yang kurang baik. Meningkatnya persaingan telah menyebabkan banyak UKM hanya mencari profitabilitas jangka pendek sehingga banyak UKM yang mengalami kegagalan. Tujuan penelitian ini adalah menguji pengaruh hubungan pelanggan dan kualitas produk terhadap kepuasan konsumen, dan pengaruh kepuasan konsumen terhadap kinerja keuangan. Penelitian ini dilakukan pada UKM dengan kriteria memliki jumlah tenaga kerja sebanyak 5-99 orang, nilai kekayaan bersih selain tanah dan gedung sebesar $\leq 500$ Juta, dan akumulasi penjualan selama 1 tahun sebesar $\leq 2,5$ Milyar. Sampel yang digunakan sebanyak 183 pemilik UKM di kabupaten Jepara yang tersebar di 16 jenis usaha. Teknik pengumpulan data menggunakan wawancara dan kuesioner dengan skala likert. Hasil penelitian menunjukkan bahwa hubungan pelanggan dan kualitas produk yang dihasilkan UKM berpengaruh positif terhadap kepuasan konsumen, sedangkan kepuasan konsumen berpengaruh positif terhadap kinerja keuangan UKM di Kabupaten Jepara. Pemilik UKM percaya bahwa memiliki hubungan pelanggan yang baik menyebabkan konsumen puas terhadap UKM dan akan menjaga loyalitas untuk membeli kembali produk yang dihasilkan sehingga dapat meningkatkan kinerja keuangan UKM.
\end{abstract}

Kata kunci: UKM, kepuasan konsumen, kinerja keuangan, kualitas produk, hubungan pelanggan

\footnotetext{
${ }^{1}$ Alamat Korespondensi:

Email: hadifeb@unisnu.ac.id
} 


\section{PENDAHULUAN}

Perekonomian Indonesia dalam beberapa tahun terakhir sangat dibantu oleh usaha kecil dan menengah (UKM). Data Badan Pusat Statistik (2017) menunjukkan UKM memberikan lapangan pekerjaan sebesar 114.144.082 orang dengan sumbangan terhadap PDB sebesar $5,89 \%$. Jumlah UKM menurut data BPS pada tahun 2013 menunjukkan 57.895.721 UKM yang ada di Indonesia. Jumlah UKM tersebut mampu melakukan ekspor sebesar Rp182.113 Milyar dengan tujuan ke berbagai Negara.

Data tersebut menjelaskan bahwa setiap tahun jumlah UKM mengalami pertumbuhan, jumlah tenaga kerja maupun sumbangan terhadap PDB Nasional serta dalam ekspor UKM juga mengalami pertumbuhan, hanya pada tahun 2009 dan 2012 yang mengalami penurunan nilai ekspor hal ini terjadi karena adanya kondisi krisis ekonomi internasional sebagai pasar ekspor UKM mengalami penurunan pertumbuhan ekonomi. Semakin banyaknya jumlah UKM yang ada berdasarkan data tersebut menciptakan sebuah persaingan bisnis yang ketat. Untuk itu pemilik UKM diharapkan terus meningkatkan kinerja perusahaannya dalam rangka mempertahankan keberlangsungan hidup bisnisnya (Mellett dan O’Brien, 2014).

Perkembangan bisnis yang semakin hari semakin kompetitif mengharuskan pemilik usaha untuk terus meningkatkan kinerja perusahaannya, salah satunya yaitu melalui kinerja keuangan perusahaan. Kinerja keuangan mempunyai pengaruh terhadap banyak hal, diantaranya nilai perusahaan, harga saham, dan juga kompensasi yang akan diterima oleh manajemen perusahaan. Selain itu, kinerja keuangan merupakan alat ukur bagi para investor terutama para pemegang saham dalam mengukur efektivitas kinerja dari manajemen perusahaan yang merupakan representasi perusahaan (Olmedo-cifuentes dan Martínez-león, 2011). Karpak dan Topcu (2010) mengidentifikasi 5 ukuran keberhasilan perusahaan sebagai berikut; 1) penjualan (pendapatan), 2) keunggulan biaya produk, 3) kualitas produk, 4) arus kas (keseimbangan) dan 5) daya tahan bertahan (viabilitas jangka panjang).

Salah satu kunci sukses pengembang bisnis adalah menjaga kualitas produk dan layanan (Namin et al. 2012). Menjaga kualitas produk dan layanan pelanggan merupakan tugas yang berat bagi UKM disisi lain persaingan antar UKM dapat menimbulkan keinginan pemilik melakukan langkah yang merugikan usahanya, yaitu dengan mempertimbangkan keuntungan jangka pendek dan menggunakan bahan baku kualitas rendah untuk menekan biaya produksi namun dapat menurunkan kualitas produknya.

Kualitas merupakan keseluruhan ciri serta sifat dari suatu produk atau pelayanan yang berpengaruh pada kemampuan untuk memuaskan kebutuhan yang dinyatakan atau yang tersirat (Kotler, 2005). Menurut Kotler dan Amstrong (2008) kualitas produk adalah kemampuan sebuah produk dalam memperagakan fungsinya, hal itu termasuk keseluruhan durabilitas, reliabilitas, ketepatan, kemudahan pengoperasian dan reparasi produk juga atribut produk lainnya. Pelanggan mendifinisikan kualitas dengan berbagai cara melalui pemenuhan harapan pelanggan. Heizer dan Render (2004) mendefinisikan kualitas sebagai kemampuan produk dan jasa memenuhi kebutuhan pelanggan.

Kualitas (produk) dan kepuasan pelanggan merupakan faktor kunci kinerja perusahaan. Kepuasan pelanggan umumnya didefinisikan sebagai perasaan atau penilaian oleh pelanggan terhadap produk atau layanan yang telah mereka gunakan (Suchanek dan Kralova, 2015). Kepuasan pelanggan bisa berarti hal yang sangat berbeda antar pelanggan, misalnya faktor waktu pengiriman, harga, kesesuaian, profesionalisme, pelanggan mimiliki tanggapan atau permintaan yang berbeda antar pelanggan (Kuronen dan Takala, 2013). Suchanek dan Kralova (2015) menunjukkan bahwa kualitas dapat dikaitkan dengan kepuasan pelanggan, atau lebih tepatnya tingkat kualitas ditentukan oleh tingkat kepuasan pelanggan.

Meningkatkan kinerja usaha UKM tidak terlepas dari peningkatan kinerja keuangan UKM yang perlu perlu mempertimbangkan faktor eksternal seperti kepuasan konsumen. Pengeran (2011) mengukur kinerja keuangan UKM dengan orientasi kewirausahaan (entrepreneurial orientation) yang didalamnya mencakup keinovasian (innovativeness), pengambilan risiko (risk taking), dan keproaktifan (proactiveness). Selanjutnya, Quantananda dan Haryadi (2015) mengatakan kinerja bisnis memiliki tiga aspek, yaitu 1) Aspek Keuangan (profit dan asset); 2) Sumber Daya Manusia (mengukur jumlah pegawai dan produktivitas pegawai melalui jumlah volume produksi); 3) Aspek Pemasaran (omzet penjualan dan frekuensi terjadinya perubahan produk). Kinerja keuangan dapat diukur melalui: tingkat kemampuan memperoleh laba, tingkat 
pengembalian investasi, dan kemampuan mencapai tujuan perusahaan secara keseluruhan (Nuvriasari dan Udjang, 2015).

Kinerja keuangan yang banyak ditemui dalam beberapa penelitian dilakukan pada perusahaan yang memiliki kemampuan manejerial yang baik, dan memiliki laporan keuangan seperti yang dilakukan oleh Fourati dan Affes (2013) meneliti tentang kinerja keungan, intelektual capital, dan nilai perusahaan di Bursa Efek Tunisia. Penelitian Gentry dan Shen (2010) membandingkan antara pengukuran profitabilitas laporan keuangan yang menggunakan Return on Assets (ROA), Return on Equity (ROE), Return on Sales (ROS), dan Return on Investment (ROI) dengan penguukuran kinerja pasar melalui market-to-book value ratio (MTB) pada perusahaan yang terdaftar di bursa Amerika. Penelitian lain tentang kinerja keuangan pada perusahaan besar antara lain Chang, (2011); Majdalany dan Henderson (2013); Mamogale (2014); Nasserinia,et al. (2014); Olmedo-cifuentes dan Martínez-león, (2011) yang menunjukkan bahwa terdapat hubungan positif antara Human Assets (HA), Relational Assets (RA), Structural Assets (SA), Human Liabilities (HL), Relational Liabilities (RL), dengan Structural Liabilities (RL) dan ROE. Selain itu, juga terdapat pengaruh positif antara kegiatan belajar organisasi terhadapa reputasi perusahaan dan kinerja perusahaan. Untuk itu peneliti tertarik melakukan penelitian tentang kinerja keuangan pada UKM yang saat ini belum memiliki laporan keuangan yang baik. Peneliti mencoba menggunakan faktor yang dapat memengaruhi kinerja keuangan perusahaan misalnya kepuasan konsumen, hubungan pelanggan, dan kualitas produk yang dilakukan pada UKM Jepara.

Tujuan penelitian ini adalah untuk menguji dan menganalisis pengaruh kualitas produk dan hubungan pelanggan dengan kepuasan konsumen terhadap kinerja keuangan UKM di Kabupaten Jepara. Hasil penelitian diharapkan dapat membantu pemilik UKM mampu meningkatkan kinerja keuangan dengan selalu menjaga hubungan baik dengan pelanggan dan kualitas produk agar konsumen merasa puas sehingga mampu mendorong konsumen untuk membeli kembali produk yang dihasilkan. Pembelian berulang konsumen tersebut akhirnya dapat meningkatkan pendapatan dan aset yang dimiliki oleh UKM.

\section{METODE}

Metode pengumpulan data yang digunakan dalam penelitian ini dengan menggunakan kuesioner. Pengumpulan data dengan menggunakan purposive sampling sesuai kriteria UKM menurut UU (Republik Indonesia, 2008) No 20 dengan karakteristik jumlah tenaga kerja sebanyak 5-99 orang, nilai kekayaan bersih selain tanah dan gedung sebesar $\leq 500$ Juta, dan akumulasi penjualan selama 1 tahun sebesar $\leq$ 2,5 Milyar. Sampel yang digunakan adalah sebanyak 183 pemilik UKM yang terdiri dari berbagai macam industri kecil dan menengah yang diambil dari 15 kecamatan yang ada di Kabupaten Jepara Jawa Tengah. Penelitian dilaksanakan bulan mei sampai agustus tahun 2017. Data diambil menggunakan kuesioner tertutup dengan menggunakan skala likert lima tingkatan yaitu: $(1$ = Sangat tidak Setuju, 2 = tidak setuju, 3 = kurang setuju, $4=$ setuju, dan 5 = Sangat Setuju).

Teknik analisa data penelitian ini menggunakan pendekatan kuantitatif dengan menggukan model struktur. Penelitian ini menggunakan bantuan smartPLS 3,0 untuk mengetahui pengaruh langsung maupun tidak langsung dari masing-masing variabel. Sebelum analisa pengaruh langsung maupun tidak langsungnya maka peneliti menguji validitas, dan reliabilitas dari konstruk. Uji validitas dalam penelitian ini adalah uji convergent validity dan uji discriminant validity. Pengujian hipotesis menggunaka uji t-test.

Convergent validity dari model pengukuran refleksif indikator dinilai berdasarkan korelasi antara item score/component score dengan construct score. Ukuran refleksif dikatakan tinggi jika berkorelasi lebih dari 0,7 dengan konstruk yang ingin diukur. Namun demikian, nilai loading 0,5 sampai 0,6 dianggap cukup (Ghozali dan Latan, 2014).

Discriminant validity dari model pengukuran dengan refleksif indikator dinilai berdasarkan cross loading pengukuran dengan konstruk. Jika korelasi konstruk dengan item pengukuran lebih besar daripada ukuran konstruk lainnya, maka hal ini menunjukkan bahwa konstruk laten memprediksi ukuran pada blok mereka lebih baik dari pada ukuran pada blok lainnya. Metode lain untuk menilai discriminat validity adalah membandingkan square root of average variance extracted (AVE) setiap konstruk dengan korelasi antara konstruk dengan konstruk lainnya dalam model. jika nilai akar AVE setiap konstruk lebih besar dari pada nilai 
korelasi antara konstruk dengan konstruk lainnya dalam model, maka dikatakan memiliki nilai discriminant validity yang baik. AVE dapat dihitung dengan rumus:

$$
A V E=\frac{\sum \lambda t^{2}}{\sum \lambda t^{2}+\sum t \operatorname{Var}(c t)}
$$

dimana $\lambda \mathrm{t}$ adalah komponen loading ke indikator dan $\operatorname{Var}(\mathrm{ci})=1-\lambda \mathrm{t}^{2}$. Direkomendasikan nilai AVE harus lebih besar dari 0,5 .

Composite reliability blok yang mengukur suatu konstruk dapat dievaluasi dengan dua macam ukuran, yaitu internal consistency dan cronbach alpha. Dengan output yang dihasilkan oleh PLS maka Composite reliability dapat dihitung dengan rumus:

$$
p c=\frac{\left(\sum \lambda t^{2}\right)}{\left(\sum \lambda t^{2}\right)+\sum t \operatorname{Var}(c i)}
$$

dimana $\lambda \mathrm{t}$ adalah komponen loading ke indikator dan Var (ci) $=1-\lambda t^{2}$. Uji ini terpenuhi jika Composite reliability $>0,7$.

Kualitas produk menurut Heizer and Render (2016) merupakan kemampuan produk dan jasa memenuhi kebutuhan pelanggan. Kualitas merupakan sebuah bentuk dari harapan dan keinginan pelanggan yang diukur oleh kemampuan sebuah produk. Sehingga jika produk memiliki kualitas konsumen akan merasa puas karena harapan dari produk yang dibeli terpenuhi.

Kotler and Keller (2012) menyatakan bahwa perusahaan harus memperhatikan tingkat kepuasan pelanggannya karena internet menyediakan sarana bagi konsumen untuk menyebarkan berita buruk dengan cepat dan juga berita baik ke seluruh dunia. Perusahaan yang meraih peringkat kepuasan pelanggan yang tinggi memastikan pasar sasarannya terpenuhi. Kepuasan yang tinggi akan menimbulkan keinginan untuk membeli kembali pada produk yang dihasilkan, hal ini dapat meningkatkan pendapatan maupun laba UKM. Sehingga kepuasan konsumen dapat berpengaruh positif terhadap kinerja keuangan.

Kerangka penelitian pada Gambar 1 menunjukkan bahwa hubungan pelanggan dapat berpengaruh positif terhadap kepuasan konsumen. Hubungan pelanggan adalah cara usaha pemasaran pada pelanggan dalam meningkatkan pertumbuhan jangka panjang perusahaan dan kepuasan maksimum pelanggan pelanggan yang baik merupakan suatu aset apabila ditangani dan dilayani dengan baik akan memberikan pendapatan dan pertumbuhan jangka panjang bagi suatu badan usaha (Sucahyo et al. 2013). Selanjutnya, hipotesis penelitian ini adalah sebagai berikut: 1) Variabel hubungan pelanggan berpengaruh positif terhadap kepuasan konsumen; 2) Variabel kualitas produk berpengaruh positif terhadap kepuasan konsumen; dan 3) Variabel kepuasan kosumen berpengaruh positif terhadap kinerja keuangan.

\section{HASIL}

\section{Profil Responden}

Berdasarkan Tabel 1 dapat diketahui bahwa sebagian besar respoden dalam penelitian ini berada pada kisaran usia 40-49 tahun sebanyak 34\%, dan kisaran usia 30-39 tahun sebanyak 26\%. Hal ini menunjukan dari segi umur/usia responden merupakan usia produktif yang dapat mendorong kretivitas pengusaha UKM dalam meningkatkan keuangan UKM. Jenis kelamin responden dalam penelitian ini sebagian besar merupakan laki-laki sebanyak $68 \%$ sedangkan perempuan sebnyak $32 \%$ sebagaimana terlihat dalam Tabel 1. Data tersebut menunjukkan bahwa kegiatan UKM di kabupaten Jepara rata-rata dilakukan oleh laki-laki dikarenakan proses pembuatan produk UKM masih menggunakan teknik manual.

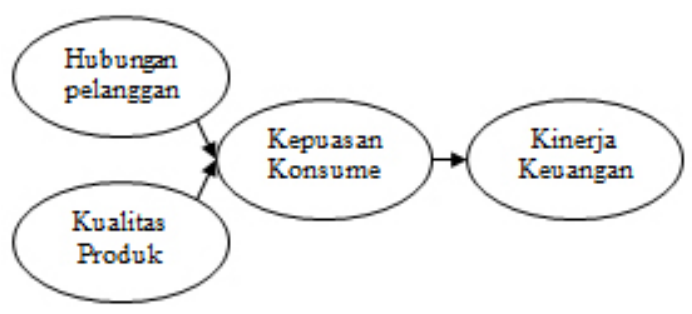

Gambar 1. Kerangka penelitian

Tabel 1. Profil responden penelitian

\begin{tabular}{llcc}
\hline \multicolumn{1}{c}{ Profil } & \multicolumn{1}{c}{ Kategori } & Jumlah & Persentase \\
\hline Umur & $<20$ & 0 & $0 \%$ \\
& $20-29$ & 32 & $17 \%$ \\
& $30-39$ & 47 & $26 \%$ \\
& $40-49$ & 63 & $34 \%$ \\
Jenis & $\geq 50$ & 41 & $22 \%$ \\
Kelamin & Laki-Laki & 125 & $68 \%$ \\
Tingkat & Perempuan & 59 & $32 \%$ \\
Pendidikan & SD Sederajat & 50 & $27 \%$ \\
& SMP Sederajat & 54 & $30 \%$ \\
& SMA Sederajat & 62 & $34 \%$ \\
& Diploma & 2 & $1 \%$ \\
& Sarjana S1 & 15 & $8 \%$ \\
\hline
\end{tabular}


Tingkat pendidikan seseorang mencerminkan tidakan dalam mengelola usahanya. Kemampuan dalam mengelola usaha akan memperlihatkan kematangan pengambil keputusan yang dapat dipengaruhi tingkat pengetahuan dan wawasan seseorang. Pengetahuan dan wawasan yang luas dapat tercermin dari tingkat pendidikan, maka semakin tinggi tingkat pendidikan orang akan berpengetahuan dan berwawasan tinggi yang dapat meningkatkan kemampuan dalam mengelola usaha dengan baik sehingga dapat meningkatkan kinerja keuangan usahanya. Sebagian besar responden berpendidikan SMA/MA/SMK, yaitu sebanyak $34 \%$. Pengusaha yang menjadi responden yang lulus perguruan tinggi atau sarjana sebanyak $8 \%$.

\section{Profil Usaha}

Lama usaha mencerminkan kemampuan seseorang dalam menjalankan usahanya. Perusahaan didirikan untuk jangka waktu yang panjang, hal ini membutuhkan kemampuan dalam mengoperasikan usahanya agar selalu mendapatkan laba guna dapat tetap bertahan dan tidak mengalami kebangkrutan. Dari Tabel 2 terlihat bahwa lama usaha yang paling rendah adalah kurang dari 5 tahun sebanyak $15 \%$ dan rentang waktu yang paling lama adalah lebih dari 20 tahun sebanyak 30\%. Sedangkan jenis usaha yang masuk dalam penelitian ini sebanyak 16 jenis usaha dan jumlah paling banyak adalah furniture.

\section{Uji Validitas dan Uji Reliabilitas Instrumen}

Menguji validitas dan reliabilitas yang merpresentasikan setiap konstruk dapat diketahui dengan melihat convergent validity yang diukur dengan nilai Average Variance Extracted (AVE) dimana nilai AVE harus lebih besar dari 0,5. Data penelitian yang digunakan menunjukkan bahwa seluruh konstruk yang digunakan memiliki nilai AVE lebih dari 0,5 yang menunjukkan bahwa data memiliki convergent validity yang baik. Sedangkan, Uji Validitas diskriminan dilakukan dengan membandingkan akar kuadrat dari AVE terhadap nilai korelasi antar konstruk. Perhitungan menggunakan smartPLS 3,0 menunjukkan bahwa nilai akarkuadratAVE lebih tinggi dibandingkan dengan nilai korelasi antar konstruk maka dinyatakan memenuhi kriteria Discriminant validity. Hasil uji validitas dan uji reliabilitas selengkapnya pada Tabel 3. Selanjutnya, Hasil Uji Discriminant Validity pada Tabel 4.
Tabel 2. Profil usaha responden penelitian

\begin{tabular}{llcc}
\hline Profil & \multicolumn{1}{c}{ Kategori } & Jumlah & Persentase \\
\hline Lama & $<5$ Tahun & 28 & $15 \%$ \\
Usaha & 5-9 Tahun & 39 & $21 \%$ \\
& 10-14 Tahun & 34 & $19 \%$ \\
& 15-19 Tahun & 27 & $15 \%$ \\
& $\geq 20$ & 55 & $30 \%$ \\
Jenis & Monel & 13 & $7 \%$ \\
Usaha & Mainan Anak & 18 & $10 \%$ \\
& Makanan & 10 & $5 \%$ \\
& Konveksi & 20 & $11 \%$ \\
& Bordir & 2 & $1 \%$ \\
& Tenun Ikat & 12 & $7 \%$ \\
& Furniture & 27 & $15 \%$ \\
& Kerajinan Rotan & 22 & $12 \%$ \\
& Rebana & 17 & $9 \%$ \\
& Genteng & 14 & $8 \%$ \\
& Sablon & 1 & $1 \%$ \\
& Gerabah & 7 & $4 \%$ \\
& Kerajinan Lencana & 1 & $1 \%$ \\
& Alumunium & 3 & $2 \%$ \\
& Batu Bata & 12 & $7 \%$ \\
Kaligrafi & 4 & $2 \%$ \\
\hline
\end{tabular}

Tabel 3. Hasil uji validitas dan uji reliabilitas

\begin{tabular}{lccc}
\hline & $\begin{array}{c}\text { Cronbach's } \\
\text { Alpha }\end{array}$ & $\begin{array}{c}\text { Composite } \\
\text { Reliability }\end{array}$ & $\begin{array}{c}\text { Average Variance } \\
\text { Extracted (AVE) }\end{array}$ \\
\hline $\begin{array}{l}\text { Hubungan } \\
\text { pelanggan }\end{array}$ & 0,700 & 0,819 & 0,603 \\
$\begin{array}{l}\text { Kepuasan } \\
\text { konsumen }\end{array}$ & 0,687 & 0,809 & 0,515 \\
$\begin{array}{l}\text { Kinerja } \\
\text { keuangan }\end{array}$ & 0,787 & 0,863 & 0,612 \\
$\begin{array}{l}\text { Kualitas } \\
\text { produk }\end{array}$ & 0,653 & 0,811 & 0,590 \\
\hline
\end{tabular}

Tabel 4. Hasil uji discriminant validity

\begin{tabular}{lcccc}
\hline & $\begin{array}{c}\text { Hubungan } \\
\text { pelanggan }\end{array}$ & $\begin{array}{c}\text { Kepuasan } \\
\text { konsumen }\end{array}$ & $\begin{array}{c}\text { Kinerja } \\
\text { keuangan }\end{array}$ & $\begin{array}{c}\text { Kualitas } \\
\text { produk }\end{array}$ \\
\hline $\begin{array}{l}\text { Hubungan } \\
\text { pelanggan }\end{array}$ & 0,777 & & & \\
$\begin{array}{l}\text { Kepuasan } \\
\text { konsumen }\end{array}$ & 0,361 & 0,717 & & \\
$\begin{array}{l}\text { Kinerja } \\
\text { keuangan }\end{array}$ & 0,263 & 0,584 & 0,783 & \\
$\begin{array}{l}\text { Kualitas } \\
\text { produk }\end{array}$ & 0,232 & 0,557 & 0,433 & 0,768 \\
\hline
\end{tabular}


Uji reliabilitas dapat diukur dengan nilai Cronbach's Alpha dimana menurut Nunnaly dalam (Jogiyanto, 2016) mengusulkan ditahap awal riset, nilai reliabilitas 0,50 sampai 0,60 dianggap cukup. Hasil perhitungan Cronbach's Alpha dengan bantuan smartPLS 3,0 menunjukkan bahwa konstruk yang reliabilitasnya dianggap cukup adalah kepuasan konsumen dan kualitas produk, sedangkan konstruk hubungan pelanggan dan kinerja keuangan memiliki tingkat reliabilitas yang tinggi. Namun, jika melihat hasil Composite reliability menunjukkan bahwa seluruh konstruk memiliki nilai lebih dari 0,7 dapat diartikan bahwa seluruh instrumen konstruk dinyatakan reliabel.

\section{Pengujian Hipotesis}

Pengujian hipotesis merupakan tahapan dalam menguji kenyataan dari dugaan sementara dari penelitian. Penelitian ini menguji pengaruh hubungan pelanggan, kualitas produk degan kepuasan konsumen dan kinerja keuangan dengan melihat hasil perhitungan path coeffisients yang membandingkan t-statistik dengan t-tabel. Hipotesis penelitian akan diterima jika nilai t-statistik lebih besar dari t-tabel $(1,653)$ dengan tingkat kepercayaan $95 \%$ atau $s i g<0,05$. Tabel 5 menunjukkan bahwa t-statistik lebih besar dari t-tabel, uji hipotesis secara individu secara keseluruhan menolak Ho yang artinya masing-masing variabel independen berpengaruh positif terhadap variabel dependen.

Hubungan Pelanggan Berpengaruh Positif Terhadap Kepuasan Konsumen

Hubungan pelanggan adalah usaha pemasaran pada pelanggan dalam rangka meningkatkan pertumbuhan jangka panjang perusahaan dan kepuasan konsumen. Pelanggan yang puas merupakan suatu aset apabila ditangani dan dilayani dengan baik akan memberikan pendapatan dan pertumbuhan jangka panjang bagi UKM. Perhitungan t-statistik menunjukkan 4,329 > 1,653 artinya hubungan pelanggan berpengaruh positif dan siginifikan terhadap kepuasan konsumen, hasil ini membuktikan hipotesis pertama. Variabel hubungan pelanggan memiliki pengaruh langsung dan pengaruh tidak langsung terhadap kinerja keuangan. Pemilik UKM yakin bahwa memiliki hubungan pelanggan yang baik menyebabkan konsumen puas terhadap UKM dan akan menjaga loyalitas untuk membeli kembali yang dapat meningkatkan kinerja keuangan UKM. Hal ini sesuai dengan penelitian Liviu dan Claudia (2013) yang menunjukkan bahwa terdapat hubungan yang kuat antara kualitas pelayanan terhadap kepuasan konsumen dan kepuasan konsumen berpengaruh terhadap kinerja perusahaan.

Hubungan pelanggan merupakan suatu proses mendapatkan, mempertahankan, dan mengembangkan pelanggan yang menguntungkan dan memerlukan fokus yang jelas terhadap atribut suatu jasa yang dapat menghasilkan nilai kepada pelanggan sehingga dapat menghasilkan loyalitas. Penelitian Kassim dan Abdullah (2010) menemukan bahwa kualitas layanan yang dirasakan ternyata berpengaruh signifikan terhadap kepuasan pelanggan. Pada gilirannya kepuasan pelanggan ternyata memiliki pengaruh yang signifikan terhadap kepercayaan. Kepuasan dan kepercayaan pelanggan memiliki pengaruh signifikan terhadap loyalitas yang berdampak pada perusahaan dalam jangka panjang. Sedangkan, Deng et al. (2010) menyatakan kepercayaan pelanggan, kualitas layanan yang dirasakan, nilai pelanggan yang dirasakan, termasuk nilai fungsional dan nilai emosional, berkontribusi terhadap kepuasan pelanggan. Selain itu juga mendukung penelitian di Ceko (Piknova, 2016) dan di Turki (Yuksel et al. 2010).

Tabel 5. Hasil perhitungan total effect

\begin{tabular}{lccc}
\hline & Original Sample & T Statistics & P Values \\
\hline Hubungan pelanggan $\rightarrow$ Kepuasan konsumen & 0,245 & 4,329 & 0,000 \\
Hubungan pelanggan $\rightarrow$ Kinerja keuangan & 0,143 & 4,160 & 0,000 \\
Kepuasan konsumen $\rightarrow$ Kinerja keuangan & 0,584 & 9,905 & 0,000 \\
Kualitas produk $\rightarrow$ Kepuasan konsumen & 0,500 & 8,839 & 0,000 \\
Kualitas produk $\rightarrow$ Kinerja keuangan & 0,292 & 6,313 & 0,000 \\
\hline
\end{tabular}


Kualitas Produk Berpengaruh Positif Terhadap Kepuasan Konsumen

Konsumen berharap produk yang dibeli melebihi kualitas yang diiklankan. Kualitas ditentukan oleh spesifikasi yang ditawarkan. Spesifikasi itu berkaitan dengan ketepatan, waktu, dan kualitas produknya. Kualitas produk menunjukkan seberapa baik produk mencapai tujuan yang dimaksudkan pada harga yang dibayar pelanggan, seberapa besar rasa cocok pelanggan, gaya, daya tahan, keandalan, keahlian, dan kegunaan produk. Hasil penelitian mampu membuktikan hipotesis kedua, hal ini menunjukkan bahwa variabel kualitas produk berpengaruh positif dan signifikan terhadap kepuasan konsumen. Variabel kualitas produk juga memiliki pengaruh langsung dan tidak langsung terhadap kinerja keuangan. UKM di Kabupaten Jepara percaya dengan kualitas produk yang baik dapat meningkatkan kepuasan konsumen dan meningkatkan penjualan yang berdampak pada peningkatan kinerja keuangan. UKM selalu berupaya membuat produk sesuai dengan kebutuhan masyarakat dengan spesifikasi yang beda dari produk UMKM lain dan berusaha membuat produk yang terkini bagi konsumen, produk yang dihasilkan sebanding dengan harga produk yang dibayar konsumen dan mudah digunakan. UKM juga memberikan ruang untuk kritik dan saran untuk perbaikan produk. Irawati et al. (2015) di Koperasi peternak Galur Murni Di Kabupaten Jember mengemukakan bahwa strategi yang dilakukan dengan mengupayakan peningkatan penjualan dengan cara memperbaiki dan memodifikasi produk yang sudah ada. Pengembangan produk ini dilakukan dengan menyempurnakan produk atau mempersiapkan untuk mengeluarkan produk baru.

Penelitian ini mendukung dari penelitian Zahra et al. (2015) menyatakan bahwa produk yang komplet dan berkualitas memiliki hubungan dengan kepuasan konsumen guna mendorong tingkat keuntungan. Penelitian Yu et al. (2005) menunjukkan bahwa harapan pelanggan pada produk memiliki dampak langsung terhadap kualitas yang dirasakan pelanggan dan berpengaruh terhadap keseluruhan tingkat kepuasan pelanggan. Selain itu hasil penelitian ini mendukung penelitian di kota Tehran Iran (Saeednia dan Valahzaghard, 2012) dan di Romania (Liviu dan Claudia, 2013).
Kepuasan Kosumen Berpengaruh Positif Terhadap Kinerja Keuangan

Kepuasan konsumen merupakan tingkat perasaan konsumen setelahmembandingkanantarakinerjaproduk perusahaan yang diterimanya dengan kinerja produk perusahaan yang diharapkannya. Yang berarti bahwa tingkat kepuasan merupakan fungsi dari perbedaan antara harapan dan kinerja. Perusahaan yang fokus pada pelanggan maka kepuasan pelanggan merupakan tujuan dan sarana pemasaran guna peningkatan penjualannya. Konsumen percaya bahwa produk UKM memiliki manfaat, tidak hanya jangka pedek namun juga jangka panjang. Hasil penelitian mendukung hipotesis ketiga, dimana kepuasan konsumen memiliki pengaruh positif dan signifikan terhadap kinerja keuangan UKM.

Kepuasan konsumen akan memberikan dampak pada promosi gratis lewat rekomendasi pelanggan ke palanggan baru, sehingga UKM perlu mempertimbangkan kualitas produk agar tetap terjaga dan citra dari produk serta pelayanan terhadap pelanggan, membina hubungan baik dengan pelanggan. Hal ini dapat meningkatkan penjualan, keuntungan serta meningkatkan kinerja keuangan UKM. Hasil penelitian menunjukkan bahwa kepuasan konsumen berpengaruh positif dan signifikan terhadap kinerja keuangan UKM. Hal ini sesuai penelitian Yeung dan Ennew (2000) yang menggunakan data dari American Consumer Satisfaction Index menunjukkan bahwa kepuasan konsumen memang memiliki dampak positif terhadap keuangan perusahaan. Selain itu penelitian (Suchanek dan Kralova, 2015) yang meneliti pada industri makanan di Republik Ceko, penelitian Wu (2013) di Hongkong, dan penelitian Dimyati (2015); Felicia (2016); Rashid et al. (2016).

Hasil pengujian hipotesis penelitian ini menunjukkan bahwa pemilik UKM perlu meningkatkan hubungan dengan pelanggan dan kualitas produk agar konsumen merasa puas. Pemilik UKM sebagai pemegang sentral usaha perlu meningkatkan kepuasan konsumen dengan selalu menjaga kualitas produk yang dihasilkan dan selalu melakukan inovasi produk, serta menjaga hubungan baik dengan konsumen agar konsumen selalu loyal dan membeli kembali produk sehingga dapat meningkatkan penjualan, keuntungan, dan asset yang dijadikan pengukur kinerja keuangan UKM. Penelitian kinerja keuangan UKM yang dilihat dari 
faktor lain selain hasil laporan keuangan ini mendukung penelitian yang sudah dilakukan Ismanto (2016) yang menghasilkan kinerja keuangan dipengaruhi oleh kemampuan manajemen, strategi bisnis, dan orientasi pasar.

\section{Implikasi Manajerial}

UKM perlu upaya nyata dalam menjaga hubungan dengan pelanggan dan menjaga kualitas produk agar konsumen merasa puas sehingga pelanggan mau untuk terus membeli produk dan dapat meningkatkan kinerja keuangan UKM. UKM perlu menitikberatkan pada proses produksi yang konsisten dalam menghasilkan produk berkualitas, memiliki nilai, gaya, serta dapat mengikuti selera pelanggan sehingga pelanggan merasa senang, puas dan menjadi loyal.

\section{KESIMPULAN DAN SARAN}

\section{Kesimpulan}

Hasil penelitian pada UKM di Kabupaten Jepara menunjukkan bahwa variabel hubungan pelanggan memiliki pengaruh positif dan signifikan terhadap kinerja keuangan baik secara langsung maupun tidak langsung melalui kepuasan konsumen. Variabel kualitas produk juga memiliki pengaruh positif dan signifikan terhadap kinerja keuangan baik secara langsung maupun tidak langsung melalui kepuasan konsumen. Sedangkan variabel kepuasan konsumen berpengaruh positif dan signifikan terhadap kinerja keuangan. Hasil penelitian menunjukkan bahwa UKM di Kabupaten Jepara memiliki kesadaran bahwa hubungan pelanggan yang baik dan kualitas produk yang baik dapat memengaruhi kinerja keuangan UKM melalui kepuasan konsumen. Konsumen yang puas akan memberikan efek terhadap penjualan dimana konsumen dapat membantu secara tidak langsung dengan promosi pada palanggan baru, sehingga penjualan produk UKM mengalami peningkatan.

\section{Saran}

Pelanggan yang loyal akan selalu membeli produk yang dihasilkan sehingga dapat meningkatkan pendapatan, laba, dan aset UKM. Untuk itu UKM perlu memperhatikan lebih pada kualitas poduk dan selalu menjaga hubungan baik dengan pelanggan agar konsumen selalu puas. Saran untuk penelitian selanjutnya adalah perlu ditambahkan variable lain seperti produktivitas karyawan, legalitas, strategi bisnis, dan perencanaan keuangan (Hamdani and Wirawan, 2012) .

\section{DAFTAR PUSTAKA}

Badan Pusat Statistik. 2017. Tabel Perkembangan UMKM pada Periode 1997-2013. Jakarta: BPS. Chang YB. 2011. Does RFID improve firms' financial performance? an empirical analysis. Information Technology and Management 12: 273-285. https://doi.org/10.1007/s10799-011-0088-3.

Deng Z, Lu Y, Wei KK, Zhang J. 2010. Understanding customer satisfaction and loyalty: An empirical study of mobile instant messages in China. International Journal of Information Management 30: 289-300. https://doi. org/10.1016/j.ijinfomgt.2009.10.001.

Dimyati M. 2015. The role of customer satisfaction in mediating marketing communication effect on customer loyalty. Journal of Arts Science and Commerce 6: 75-88. https://doi.org/10.18843/ rwjasc/v6i4(1)/09.

Felicia S. 2016. The relationship marketing application in small and medium-sized enterprises. University Constantin Brancusi of Targu-Jiu Social Sciences 1:42-47.

Fourati H,Affes H. 2013. Intellectual capital investment, stakeholders' value, firm market value and financial performance: the case of tunisia stock exchange. Journal of Information \& Knowledge Management 12: 1350010-1-1350010-12. https://doi.org/10.1142/S021964921350010X.

Gentry RJ, Shen W. 2010. The relationship between accounting and market measures of firm financial performance: how strong is it? Journal of Management 22: 514-530.

Ghozali I, Latan H. 2014. Partial Least Squares, Konsep, Teknik, dan Aplikasi, 2nd ed. Semarang: Badan Penerbit Universitas Diponegoro.

Hamdani J, Wirawan C. 2012. Open innovation implementation to sustain indonesian SMEs. Procedia Economics and Finance 4: 223-233. https://doi.org/10.1016/S2212-5671(12)00337-1

Heizer J, Render B. 2016. Operations Management, 11th ed. New Jersey:Pearson Education, Inc.

Irawati DA, Hubeis M, Muksin M. 2015. Strategi pengembangan koperasi peternak galur murni di Kabupaten Jember. Jurnal Aplikasi Bisnis 
dan Manajemen 3(1): 123-130. https://doi. org/10.17358/jabm.3.1.123.

Ismanto H. 2016. Analisis kinerja keuangan UMKM tenun ikat troso jepara. Journal of Economics. 12: 159-166.

Jogiyanto. 2016. Pedoman Survei Kuesioner: Mengembangkan Kuesioner, Mengatasi Bias, Meningkatkan Respon, 2nd ed. Yogyakarta: BPFE UGM,

Karpak B, Topcu I. 2010. Small medium manufacturing enterprises in Turkey: An analytic network process framework for prioritizing factors affecting success. International Journal of Production Economics 125: 60-70. https://doi. org/DOI: 10.1016/j.ijpe.2010.01.001.

Kassim N, Abdullah NA. 2010. The effect of perceived service quality dimensions on customer satisfaction, trust, and loyalty in e-commerce settings A cross ultural analysis. Asia Pacific Journal of Marketing and Logistics 22: 351-371. https://doi.org/10.1108/13555851011062269.

Kotler P, Keller KL. 2012. Marketing Management, 14th ed. New Jersey: Prentice Hall.

Kuronen M, Takala J. 2013. Measuring And Developing Customer Satisfaction - With The Balanced Critical Factor Index Method, in: International Conference on Technology Innovation and Industrial Management. pp. 236-244.

Liviu, Claudia A. 2013. Customer services and product quality. Annals of the 'Constantin Brâncuşi' University of Targu Jiu-Letters and Social Sciences Series 2: 73-79.

Majdalany G, Henderson J. 2013. Voluntary disclosure of intellectual assets and intellectual liabilities: impact on financial performance in publicly listed firms in the United Arab Emirates. Electronic Journal of Knowledge Management 11: 325-338.

Mamogale MJ. 2014. Financial performance of local government in Limpopo province, 2010-2012. African Studies Quarterly 15: 71-92.

Mellett S, O’Brien E. 2014. Irish SMEs and e-learning implementation: the strategic innovative approach. British Journal of Educational Technology 45: 1001-1014. https://doi. org/10.1111/bjet.12186.

Namin AT, Pilevary N, Namin AT. 2012. Measuring customer satisfaction using SERQUAL survey. Management Science Letters 2: 933-938.

Nasserinia A, Ariff M, Fan-Fah C. 2014. Key determinants of japanese commercial banks performance. Pertanika Journal of Social Science and Humanities 22: 17-38.

Nuvriasari A, Udjang R. 2015. Peran Pengelolaan Hubungan Pelanggan Dan Pengelolaan Rantai Pasokan Terhadap Kinerja Ukm, in: Seminar Nasional Hasil-Hasil Penelitian dan Pengabdian LPPM Universitas Muhammadiyah Purwokerto. pp. 174-183.

Olmedo-cifuentes I, Martínez-león I. 2011. Organizational learning and corporate reputation: relations and effects on financial performance. European Conference on Knowledge Management 889-899.

Pengeran P. 2011. Orientasi kewirausahaan dan kinerja keuangan pengembangan produk baru usaha mikro dan kecil. Jurnal Riset Manajemen dan Bisnis 6: 113-125.

Piknova A. 2016. Developing relations with customers: presentation of different viewpoints, in: $C B U$ International Conference On Innovations In Science And Education. pp. 21-25.

Quantananda E, Haryadi B. 2015. Pengaruh Orientasi Kewirausahaan Pada Perusahaan Makanan dan Minuman di Surabaya. AGORA 3: 706-714.

Rashid AA, Rahmati MH, Jandaghi G. 2016. The mediating role of customer satisfaction and customer-company identification in the rrelationship between corporate social responsibility and customer loyalty (Case study: customer' s pasargad Bank). World Scientific News 50: 117-130.

Saeednia HR, Valahzaghard SK. 2012. A study to measure the impact of customer perception, quality, environment concern and satisfaction on green customer loyalty. Management Science Letters 2: 2881-2888.

Sucahyo AD, Dh AF, Arifin Z. 2013. Analisispengaruh custoer relationship marketing pemasaran hubungan pelanggan dalam meningkatkan kepuasan dan loyalitas (Survei Pada Nasabah Bank Tabungan Pensiunan Nasional Mitra Usaha Rakyat Kantor Cabang Bojonegoro). e-Jurnal Ilmu Adm. Univ. Brawijaya 7: 151-156. https:// doi.org/10.9876/10.9876/VOL1ISSN1978$743 \mathrm{X}$.

Suchanek P, Kralova M. 2015. Effect of customer satisfaction on company performance. Acta Universitatis Agriculturae et Silviculturae Mendelianae Brunensis 63: 1013-1021. https:// doi.org/10.11118/actaun201563031013. 
Wu ML. 2013. Linking Resource-Based Strategies to customer-focused performance for professional services: a structural equation modelling approach. International Journal of Knowledge Management 2: 165-184.

Yeung $\mathrm{MCH}$, Ennew CT. 2000. From customer satisfaction to profitability. Journal of Strategic Marketing 8(4): 313-326. https://doi. org/10.1080/09652540010003663.

Yu CJ, Wu L, Chiao Y, Tai H. 2005. Perceived quality, customer satisfaction, and customer loyalty: the case oflexusinTaiwan. TotalQualityManagement
\& Business Excellence 16(6): 707-719. https:// doi.org/10.1080/14783360500077393.

Yuksel A, Yuksel F, Bilim Y. 2010. Destination attachment: Effects on customer satisfaction and cognitive, affective and conative loyalty. Tourism Management 31(2): 274-284. https:// doi.org/10.1016/j.tourman.2009.03.007.

Zahra J, Tatari E, Sameie G, Motalebipour H. 2015. Measuring customer satisfaction: Evidence from digital library. Management Science Letters 5: 525-530. https://doi.org/10.5267/j. ms1.2015.2.012. 